\title{
Synthesis, Structure Elucidation and Application of Some New Azo Disperse Dyes Derived from 4-Hydroxycoumarin for Dyeing Polyester Fabrics
}

\author{
Moaz M. Abdou', Samir Bondock², El-Sayed I. El-Desouky², M. A. Metwally ${ }^{2, *}$ \\ ${ }^{1}$ Egyptian Petroleum Research Institute, Nasr city, P.O. 11727, Cairo, Egypt \\ ${ }^{2}$ Department of Chemistry, Faculty of Science, Mansoura University, ET-35516, Egypt
}

\begin{abstract}
As a part of our ongoing interest in disperse dyes and task specific azo dyes with better dyeing properties, we synthesized a series of 3-aryl(hetaryl)hydrazono-2,4-chromandiones 4a-k via Coupling of 4-hydroxycoumarin with diazotized aniline derivatives. Structures of the synthesized compounds have been investigated by means of UV, IR, ${ }^{1} \mathrm{H}-\mathrm{NMR}$ and mass spectroscopy in order to elucidate their tautomeric and isomeric structures. The results of such spectral data indicated that compounds 4a-k exist predominantly in the hydrazo structure (D) as a mixture of $\mathrm{Z}$ and E-isomer with ratio $\sim 84.5: 15.5$. Finally, the prepared dyestuffs $4 \mathrm{a}-\mathrm{k}$ were applied as disperse dyes for dyeing polyester fabrics and their fastness properties were evaluated. Also, the position of color in CIELAB coordinates ( $L^{*}, a^{*}, b^{*}, H^{*}, C^{*}$ and $\left.K / S\right)$ estimated and discussed.
\end{abstract}

Keywords Azo-Hydrazone Tautomerism, Disperse Dyes, Polyester Fabrics, Fastness Properties, CIELAB Coordinates

\section{Introduction}

Disperse dyes are very popular and important class of dyes for dyeing polyester fabrics owing to their brilliancy, wide range of hue and excellent fastness properties[1]. The majority of disperse dyes are azodyes due to the ease with which an extra ordinary number of molecular combinations can be generated by varying the diazo and coupling components and they provide a very wide color gamut of high color strength[2-4].

Especially useful in this respect are azodyes derived from coupling of diazonium salts with 4-hydroxycoumarin as coupling component. These azodyes are very useful as precursors for the synthesis of heterocyclic ring systems, which play an important role in pharmaceutical chemistry and dyestuff industry[5,6]. Another interesting feature of this class lies on its tautomeric behavior which

has been studied by several investigators for many years. They were originally regarded as azo-structure $(\mathbf{A})[7,8]$, but others workers[9-11] tended to the view that they were keto-hydrazone structure (D). Recently, two groups of workers $[12,13]$ proposed that compounds exist as a mixture of tautomeric forms(A) and (D) (Fig. 1).

Based on these results, the approach reported here is an

* Corresponding author:

mamegs@mans.edu.eg (M. A. Metwally)

Published online at http://journal.sapub.org/chemistry

Copyright (C) 2012 Scientific \& Academic Publishing. All Rights Reserved extension and a continuation of our interest in the synthesis and elucidation of the tautomeric structures of mono and bisazo dyes which were able to dye polyester fabrics [5,6,14-16]. Thus, this work is aiming to study the synthesis of a series of azo disperse dyes having different substituted groups 4a-k in a trial to provide a better understanding of the prevalent tautomeric structure of the compounds in question. Moreover, the prepared dyestuffs will be dyed on polyester fabrics and their dyeing properties, light fastnesses, wash fastnesses, sublimation fastnesses and the position of color in CIELAB coordinates $\left(L^{*}, a^{*}, b^{*}, H^{*}, C^{*}\right)$ were evaluated.

\section{Experimental Section}

\subsection{Materials and Instrumentation}

General: Elemental analyses were performed at the Microanalytical Center, Cairo University, using CHNS-932 (LECO) Vario Elemental Analyzers and the results were within the accepted range $( \pm 0.40)$ of the calculated values. IR spectra were obtained using a Mattson 5000 FTIR spectrometer $\left(v, \mathrm{~cm}^{-1}\right)$, using samples in $\mathrm{KBr}$ disks and only partial spectral data are listed. The Ultraviolet absorption spectra were recorded in the range $200-800 \mathrm{~nm}$ on Shimadzu 700 spectra photometer in dioxane using a concentration of $10^{-4} \mathrm{~mol} \mathrm{dm}^{-3}$. ${ }^{1} \mathrm{H}$ NMR spectra were measured on a Bruker WP300 (300 MHz) spectrometer $\left(\delta\right.$, ppm), using DMSO-d $\mathrm{d}_{6}$ as a solvent and TMS as an internal standard. Mass spectra were recorded on a Finnigan MAT 212 instrument. Scoured 
and bleached polyester $100 \%\left(150: 130 \mathrm{~g} / \mathrm{m}^{2}, 70 / 2\right.$ denier $)$ was obtained from El-Shourbagy, Egypt. The fabric was further treated before dyeing with a solution containing $5 \mathrm{~g} / \mathrm{L}$ nonionic detergent (Hostapal CV, Clariant-Egypt) and $2 \mathrm{~g} / \mathrm{L}$ sodium carbonate at a liquor ratio $20: 1$ at $60^{\circ} \mathrm{C}$ for $30 \mathrm{~min}$, thoroughly washed in water and air dried at room temperature. The dispersing agent Setamol WS was supplied by BASF (Germany). The dyeing assessment, fastness tests, and color measurements were carried out in Laboratories and Research sector in El-Nasr Company for Spinning and Weaving, El-Mahalla El-Kubra, Egypt. The colorimetric measurements $\left(L^{*}, a^{*}, b^{*}, C^{*}, H^{*}\right.$ and $\left.\mathrm{K} / \mathrm{S}\right)$ were carried out using a Gretag Macbeth CE 7000A spectrophotometer (D65 illumination, $10^{\circ}$ observer). Fastness to washing was carried out using the automatic launder Rotadyer (sponsored by the British Standard Institute-Society of Dyers and Colorists), fastness to perspiration was assessed according to the test sponsored by the (BSS), fastness to rubbing was carried out according to the standard method of testing (BSS) using Crockmeter of Electric Hungarian FD-17 type, fastness to sublimation was carried out using the Electric Japanese Thermotester T-10 type and fastness to light was carried out using the "Weather-o-meter" (Atlas Electric Devices Co. USA), AATCC standard test method.

\subsection{Synthesis and Spectroscopic Characterization}

\subsubsection{General procedure for the synthesis of 3-aryl (hetaryl)} hydrazono-2,4-chromandione derivatives 4a-i

To a stirred suspension of aromatic amine $(0.87 \mathrm{mmol})$ in water $(3 \mathrm{ml})$, concentrated $\mathrm{HCl}(2 \mathrm{ml} 5 \mathrm{M})$ was added with heating until complete dissolution of the amine hydrochloride. The resulted solution was cooled at $0^{\circ} \mathrm{C}$ on ice bath, while some solid started to precipitate. To this mixture, $\mathrm{NaNO}_{2}(0.9 \mathrm{mmol}, 60 \mathrm{mg})$ dissolved in a minimum amount of water was added slowly with vigorous stirring. The stirring was continued at low temperature for $15 \mathrm{~min}$. Then, it has been added to an ice-cooled solution of 4-hydroxycoumarin $(0.87 \mathrm{mmol})$ and sodium hydroxide $(0.87 \mathrm{mmol})$ in ethanol $(20 \mathrm{ml})$. The reaction mixture was allowed to stir at $\left(0-5^{\circ} \mathrm{C}\right)$ for $2 \mathrm{hrs}$, and then the solid was collected by filtration. The crude products thus obtained, were dried and recrystallized from acetic acid to give the corresponding compounds $4 \boldsymbol{a}-\boldsymbol{i}$.

\subsubsection{3-(2-Phenylhydrazono)-2,4-chromandione (4a) \pm (Z(Z)-3-)}

Yellow solid, Yield: $79 \%$ UV-Vis ( $\lambda_{\max }$ in dioxane): 258 , $416 \mathrm{~nm}$. IR (KBr, $\left.i_{\max } / \mathrm{cm}^{-1}\right): 3177(\mathrm{NH}), 3019(\mathrm{CH}, \mathrm{Ar}$ ), $1732(\mathrm{C}=\mathrm{O}$, lactone $), 1636(\mathrm{C}=\mathrm{O}, \mathrm{C}-4), 1611(>\mathrm{C}=\mathrm{N}), 1550$ $(\mathrm{C}=\mathrm{C}-\mathrm{NH}-\mathrm{N}=), 1330 \quad\left(\mathrm{C}_{\text {arom }}-\mathrm{N}\right) . \quad{ }^{1} \mathrm{HNMR} \quad(300 \mathrm{MHz}$, DMSO-d $\left._{6}, \delta / p p m\right): 7.26-8.04$ (m, 9H, Ar-H), 14.22 (s, NH, $E$-isomer), 16.50 (s, NH, Z-isomer). MS, $m / z(\%): 266\left(\mathrm{M}^{+}\right.$, 21), 220 (22), 174 (26), 160 (18), 146 (100), 103 (31), 98 (19), 92 (40), 87 (24), 77 (11), 76 (19), 64 (15), 63 (27). Anal. Calcd. for $\mathrm{C}_{15} \mathrm{H}_{10} \mathrm{~N}_{2} \mathrm{O}_{3}(266.07)$ : $\mathrm{C}, 67.67 \mathrm{H}, 3.79 \mathrm{~N}, 10.52 \%$, Found: C, $67.59 \mathrm{H}, 3.83 \mathrm{~N}, 10.64 \%$.

\subsubsection{3-(2-(4-Methylphenyl)hydrazono)-2, 4-chromandione (4b)}

Yellow solid, Yield: $75 \%$ UV-Vis ( $\lambda_{\max }$ in dioxane): 252 , $422 \mathrm{~nm}$. IR (KBr, $\left.i_{\max } / \mathrm{cm}^{-1}\right): 3190(\mathrm{NH}), 3033(\mathrm{CH}, \mathrm{Ar}$.), $2915(\mathrm{CH}$, Aliph. $), 1736(\mathrm{C}=\mathrm{O}$, lactone $), 1628(\mathrm{C}=\mathrm{O}, \mathrm{C}-4)$, $1604(>\mathrm{C}=\mathrm{N}), 1548 \quad(\mathrm{C}=\mathrm{C}-\mathrm{NH}-\mathrm{N}=), 1332 \quad\left(\mathrm{C}_{\text {arom. }}-\mathrm{N}\right)$. ${ }^{1} \mathrm{HNMR}(300 \mathrm{MHz}$, DMSO-d 6 , $\delta / \mathrm{ppm}): 2.54\left(\mathrm{~s}, 3 \mathrm{H}, \mathrm{CH}_{3}\right)$, 7.26-8.04 (m, 8H, Ar-H), 14.42 (s, NH, E-isomer), 16.63 (s, $\mathrm{NH}, Z$-isomer). MS m/z (\%): $280\left(\mathrm{M}^{+}, 30\right), 224$ (19), 174 (16), 161 (23), 120 (100), 118 (20), 106 (46), 98 (10), 90 (9), 84 (13), 77 (28), 67 (20), 56 (12). Anal. Calcd. for $\mathrm{C}_{16} \mathrm{H}_{12} \mathrm{~N}_{2} \mathrm{O}_{3}$ (280.08): C, $68.56 \mathrm{H}, 4.32 \mathrm{~N}, 9.99 \%$, Found: C, $68.63 \mathrm{H}, 4.24 \mathrm{~N}, 10.13 \%$.

\subsubsection{3-(2-(4-Methoxyphenyl)hydrazono)-2, 4-chromandione (4c)}

Yellow solid, Yield: $83 \%$ UV-Vis ( $\lambda_{\max }$ in dioxane): 256 , $436 \mathrm{~nm}$. IR (KBr, $\left.i_{\max } / \mathrm{cm}^{-1}\right): 3228(\mathrm{NH}), 3049(\mathrm{CH}, \mathrm{Ar}$ ), 2975 (CH, Aliph.), 1737 (C=O, lactone), $1634(\mathrm{C}=\mathrm{O}, \mathrm{C}-4)$, $1609(>\mathrm{C}=\mathrm{N}), 1555 \quad(\mathrm{C}=\mathrm{C}-\mathrm{NH}-\mathrm{N}=), 1330 \quad\left(\mathrm{C}_{\text {arom. }}-\mathrm{N}\right)$. ${ }^{1} \mathrm{HNMR}\left(300 \mathrm{MHz}, \mathrm{DMSO}-\mathrm{d}_{6}, \delta / \mathrm{ppm}\right): 3.89\left(\mathrm{~s}, 3 \mathrm{H}, \mathrm{OCH}_{3}\right)$, 7.29-8.03 (m, 8H, Ar-H), 14.11 (s, NH, E-isomer), 16.62 (s, $\mathrm{NH}, Z$-isomer). MS $m / z(\%): 296\left(\mathrm{M}^{+}, 28\right), 237$ (23), 174 (17), 161 (100), 143 (22), 122 (43), 119 (41), 108 (14), 99 (12), 85 (30), 79 (19), 73 (21), 64 (15), 62 (12). Anal. Calcd. for $\mathrm{C}_{16} \mathrm{H}_{12} \mathrm{~N}_{2} \mathrm{O}_{4}(296.28)$ : C, $64.86 \mathrm{H}, 4.08 \mathrm{~N}, 9.46 \%$, Found: C, $64.94 \mathrm{H}, 4.18 \mathrm{~N}, 9.32 \%$.

\subsubsection{3-(2-(4-Chlorophenyl)hydrazono)-2, 4-chromandione (4d)}

Yellow solid, Yield: $73 \% \mathrm{UV}-\mathrm{Vis}$ ( $\lambda_{\max }$ in dioxane): 257 , $432 \mathrm{~nm}$. IR (KBr, $\left.i_{\max } / \mathrm{cm}^{-1}\right)$ : $3200(\mathrm{NH}), 3038(\mathrm{CH}, \mathrm{Ar}$.), $1730(\mathrm{C}=\mathrm{O}$, lactone $), 1640(\mathrm{C}=\mathrm{O}, \mathrm{C}-4), 1614(>\mathrm{C}=\mathrm{N}), 1553$ $(\mathrm{C}=\mathrm{C}-\mathrm{NH}-\mathrm{N}=), 1337 \quad\left(\mathrm{C}_{\text {arom }}-\mathrm{N}\right),{ }^{1} \mathrm{HNMR} \quad(300 \mathrm{MHz}$, DMSO-d $\left._{6}, \delta / \mathrm{ppm}\right):$ 7.30-8.13 (m, 8H, Ar-H), 14.12 (s, NH, $E$-isomer), 16.13 (s, NH, $Z$-isomer). $\mathrm{MS} m / z(\%): 302\left(\mathrm{M}^{+}+2\right.$, 30), $300\left(\mathrm{M}^{+}, 50\right), 237$ (25), $188(28), 174(25), 160(17), 126$ (27), 120 (100), 103 (18), 98 (11), 95 (30), 87 (17), 86 (29), 77 (30), 76 (19), 75 (10), 64 (22), 63 (11), 62 (9). Anal. Calcd. for $\mathrm{C}_{15} \mathrm{H}_{9} \mathrm{ClN}_{2} \mathrm{O}_{3}$ (300.03): C, $59.91 \mathrm{H}, 3.02 \mathrm{~N}, 9.32 \%$, Found: C, $60.01 \mathrm{H}, 3.09 \mathrm{~N}, 9.21 \%$.

\subsubsection{3-(2-(2,4-Dichlorophenyl)hydrazono)-2, 4-chromandione (4e)}

Yellow solid, Yield: $79 \% \mathrm{UV}-\mathrm{Vis}$ ( $\lambda_{\max }$ in dioxane): 258 , $426 \mathrm{~nm}$. IR (KBr, $\left.\hat{i}_{\max } / \mathrm{cm}^{-1}\right): 3240(\mathrm{NH}), 3059(\mathrm{CH}, \mathrm{Ar}$.$) ,$ $1730(\mathrm{C}=\mathrm{O}$, lactone $), 1636(\mathrm{C}=\mathrm{O}, \mathrm{C}-4), 1611(>\mathrm{C}=\mathrm{N}), 1550$ $(\mathrm{C}=\mathrm{C}-\mathrm{NH}-\mathrm{N}=), 1330 \quad\left(\mathrm{C}_{\text {arom }}-\mathrm{N}\right),{ }^{1} \mathrm{HNMR} \quad(300 \mathrm{MHz}$, DMSO-d $_{6}, \delta / \mathrm{ppm}$ ): 7.26-8.04 (m, 7H, Ar-H), 13.88 (s, NH, $E$-isomer), 15.89 (s, NH, $Z$-isomer). $\mathrm{MS} m / z$ (\%): $335\left(\mathrm{M}^{+}+2\right.$, 14), $334\left(\mathrm{M}^{+}+1,67\right), 333\left(\mathrm{M}^{+}, 30\right), 298$ (26), 270 (24), 188 (76), 174 (39), 172 (56), 160 (65), 146 (73), 144 (92), 134 (29), 132 (49), 120 (100), 116 (37), 105 (23), 99 (59), 85 (15), 84 (69), 82 (17), 74 (34), 72 (15), 64 (16), 63 (21), 62 (19). Anal. Calcd. for $\mathrm{C}_{15} \mathrm{H}_{8} \mathrm{Cl}_{2} \mathrm{~N}_{2} \mathrm{O}_{3}(333.99)$ : $\mathrm{C}, 53.76 \mathrm{H}, 2.41 \mathrm{~N}$, $8.36 \%$, Found: C, $53.89 \mathrm{H}, 2.60 \mathrm{~N}, 8.22 \%$. 


\subsubsection{3-(2-(4-Bromophenyl)hydrazono)-2, 4-chromandione (4f)}

Yellow solid, Yield: $72 \% \mathrm{UV}-\mathrm{V}$ is ( $\lambda_{\max }$ in dioxane): 258 , $431 \mathrm{~nm}$. IR (KBr, $\left.i_{\max } / \mathrm{cm}^{-1}\right): 3170(\mathrm{NH}), 3035$ (CH, Ar.), $1734(\mathrm{C}=\mathrm{O}$, lactone $), 1638(\mathrm{C}=\mathrm{O}, \mathrm{C}-4), 1619(>\mathrm{C}=\mathrm{N}), 1546$ $(\mathrm{C}=\mathrm{C}-\mathrm{NH}-\mathrm{N}=), \quad 1334 \quad\left(\mathrm{C}_{\text {arom. }}-\mathrm{N}\right),{ }^{1} \mathrm{HNMR} \quad(300 \mathrm{MHz}$, DMSO-d $\left._{6}, \delta / p p m\right): 7.33-8.12$ (m, 8H, Ar-H), 14.31 (s, NH, $E$-isomer), 16.45 (s, NH, $Z$-isomer). $\mathrm{MS} m / z(\%)$ : $345\left(\mathrm{M}^{+}+2\right.$, 22), $343\left(\mathrm{M}^{+}, 49\right), 215$ (17), 214 (28), 203 (41), 188 (9), 174 (19), 171 (35), 161 (100), 120 (30), 119 (25), 118 (13), 114 (17), 98 (14), 90 (24), 85 (14), 84 (13), 77 (29), 55 (37). Anal. Calcd. for $\mathrm{C}_{15} \mathrm{H}_{9} \mathrm{BrN}_{2} \mathrm{O}_{3}$ (343.98): $\mathrm{C}, 52.20 \mathrm{H}, 2.63 \mathrm{~N}$, $8.12 \%$, Found: C, 52.34 H, 2.77 N, $8.30 \%$.

\subsubsection{3-(2-(4-Nitrophenyl)hydrazono)-2,4-chromandione} (4g)

Yellow solid, Yield: $87 \%$ UV-Vis ( $\lambda_{\max }$ in dioxane): 260 , $438 \mathrm{~nm}$. IR (KBr, $\left.i_{\max } / \mathrm{cm}^{-1}\right)$ : $3210(\mathrm{NH}), 3046$ (CH, Ar.), $1732(\mathrm{C}=\mathrm{O}$, lactone), $1637(\mathrm{C}=\mathrm{O}, \mathrm{C}-4), 1615(>\mathrm{C}=\mathrm{N}), 1552$ $(\mathrm{C}=\mathrm{C}-\mathrm{NH}-\mathrm{N}=), \quad 1334 \quad\left(\mathrm{C}_{\text {arom. }}-\mathrm{N}\right),{ }^{1} \mathrm{HNMR} \quad(300 \mathrm{MHz}$, DMSO-d $\left._{6}, \delta / \mathrm{ppm}\right):$ 7.28-8.06 (m, 8H, Ar-H), 13.92 (s, NH, $E$-isomer), 16.14 (s, NH, Z-isomer). $\mathrm{MS} \mathrm{m/z} \mathrm{( \% ):} 311\left(\mathrm{M}^{+}\right.$, 35), 237 (100), 174 (39), 160 (49), 144 (62), 120 (81), 116 (14), 105 (33), 99 (19), 84 (26), 82 (10), 74 (18), 63 (28), 55 (41). Anal. Calcd. for $\mathrm{C}_{15} \mathrm{H}_{9} \mathrm{~N}_{3} \mathrm{O}_{5}(311.05)$ : C, $57.88 \mathrm{H}, 2.91$ N, $13.50 \%$, Found: C, 57.76 H, 3,02 N, $13.63 \%$.

\subsubsection{3-(2-(4-diphenyldiazene)hydrazono)-2, 4-chromandione (4h)}

Orange solid, Yield: $79 \% \mathrm{UV}-\mathrm{V}$ is ( $\lambda_{\max }$ in dioxane): 258 , $426 \mathrm{~nm}$. IR (KBr, ímax $/ \mathrm{cm}^{-1}$ ): 3199 (NH), 3019 (CH, Ar.), $1731(\mathrm{C}=\mathrm{O}$, lactone $), 1636(\mathrm{C}=\mathrm{O}, \mathrm{C}-4), 1611(>\mathrm{C}=\mathrm{N}), 1552$ $(\mathrm{C}=\mathrm{C}-\mathrm{NH}-\mathrm{N}=), \quad 1340 \quad\left(\mathrm{C}_{\text {arom. }}-\mathrm{N}\right), \quad{ }^{1} \mathrm{HNMR} \quad(300 \mathrm{MHz}$, DMSO-d $\left._{6}, \delta / \mathrm{ppm}\right):$ 7.26-8.04 (m, 12H, Ar-H), 14.2 (s, NH, $E$-isomer), 16.5 (s, NH, Z-isomer). $\mathrm{MS} m / z(\%): 370\left(\mathrm{M}^{+}\right.$, 100), 266 (12), 265 (71), 237 (8), 197 (14),195 (11), 188 (28), 174 (32), 160 (17), 152 (9), 103 (27), 98 (9), 95 (30), 87 (32), 86 (13), 77 (9), 76 (97), 75 (14), 64 (15), 63 (8), 62 (7). Anal. Calcd. for $\mathrm{C}_{21} \mathrm{H}_{14} \mathrm{~N}_{4} \mathrm{O}_{3}$ (370.11): $\mathrm{C}, 68.10 \mathrm{H}, 3.81 \mathrm{~N}$, 15.13 \% , Found: C, 68.31 H, 3.90 N, $15.22 \%$.

\subsubsection{3-(2-Antipyrinylhydrazono)-2,4-chromandione}

\section{(4i) \pm}

Red solid, Yield: $75 \% \mathrm{UV}-\mathrm{V}$ is ( $\lambda_{\max }$ in dioxane): 252,439 nm. IR (KBr, ímax $/ \mathrm{cm}^{-1}$ ): $3220(\mathrm{NH}), 3080$ (CH, Ar.), 2956 (CH, Aliph.), $1740(\mathrm{C}=\mathrm{O}$, lactone), 1660, $1635(\mathrm{C}=\mathrm{O}$, C-4/pyrazolone), $1613(>\mathrm{C}=\mathrm{N}), 1548(\mathrm{C}=\mathrm{C}-\mathrm{NH}-\mathrm{N}=), 1332$ $\left(\mathrm{C}_{\text {arom. }}-\mathrm{N}\right) .{ }^{1} \mathrm{HNMR}\left(300 \mathrm{MHz}, \mathrm{DMSO}-\mathrm{d}_{6}, \delta / \mathrm{ppm}\right): 2.42(\mathrm{~s}$, $\left.3 \mathrm{H}, \mathrm{CH}_{3}\right), 3.29$ (s, 3H, N-CH$)_{3}, 7.17-8.24$ (m, 13H, Ar-H), 14.09 (s, NH, $E$-isomer), 16.22 (s, NH, $Z$-isomer). MS $m / z$ (\%): $378\left(\mathrm{M}^{+}, 21\right), 216$ (19), 203 (40), 201 (24), 188 (14), 174 (24), 161 (100), 120 (76), 114 (18), 98 (26), 84 (28), 67 (15), 56 (31), 55 (12). Anal. Calcd. for $\mathrm{C}_{20} \mathrm{H}_{18} \mathrm{~N}_{4} \mathrm{O}_{4}$ (378.13): C, 63.48 H, 4.79 N, $14.81 \%$, Found: C, 63.62 H, $4.91 \mathrm{~N}$, $14.69 \%$.

\subsubsection{General Procedure for the Synthesis of Bis Hydrazono Derivatives $\mathbf{4} \mathbf{j}$ and $\mathbf{4 k}$}

The corresponding aryl diazonium chloride was prepared by adding cold sodium nitrite solution ( $1.2 \mathrm{gm}$ in $12 \mathrm{ml} \mathrm{H}_{2} \mathrm{O}$ ) to a cold suspension of $p$-phenylenediamine and/or benzidine ( $1.74 \mathrm{mmol})$ in concentrated $\mathrm{HCl}(6 \mathrm{ml})$ with stirring at low temperature for $15 \mathrm{~min}$. Then, it has been added to an ice-cooled solution of 4-hydroxycoumarin $(0.87 \mathrm{mmol})$ and sodium hydroxide $(0.87 \mathrm{mmol})$ in ethanol $(20 \mathrm{ml})$. The reaction mixture was allowed to stir at $\left(0-5{ }^{\circ} \mathrm{C}\right)$ for $2 \mathrm{hrs}$, and then the solid was collected by filtration. The crude products thus obtained, were dried and recrystallized from from ethanol-DMF mixture (1:2) to give the corresponding compounds $\mathbf{4} \mathbf{j}$ and $\mathbf{4 k}$.

\subsubsection{3,3`-(1,4-dihydrazonobenzene) bis(2, 4-chromandione) $(\mathbf{4 j})$}

Brown solid, Yield: $81 \%$ IR (KBr, $\left.i_{\max } / \mathrm{cm}^{-1}\right): 3227(\mathrm{NH})$, 3019 ( $\mathrm{CH}, \mathrm{Ar}$ ), $1738(\mathrm{C}=\mathrm{O}$, lactone), $1635(\mathrm{C}=\mathrm{O}, \mathrm{C}-4)$, $1610(>\mathrm{C}=\mathrm{N}), 1552(\mathrm{C}=\mathrm{C}-\mathrm{NH}-\mathrm{N}=), 1338\left(\mathrm{C}_{\text {arom. }}-\mathrm{N}\right), \mathrm{MS} m / \mathrm{z}$ (\%): $469\left(\mathrm{M}^{+}, 10\right), 397$ (12), 389 (8), 380 (11), 356 (9), 161 (76), 143 (41), 136 (15), 121 (46), 119 (100), 108 (14), 99 (17), 85 (14), 84 (70), 79 (9), 78 (17), 77 (14), 73 (15), 67 (12), 64 (11), 63 (19), 62 (18), 60 (11), 56 (15). Anal. Calcd. for $\mathrm{C}_{25} \mathrm{H}_{17} \mathrm{~N}_{4} \mathrm{O}_{6}$ (469.11): $\mathrm{C}, 63.96 \mathrm{H}, 3.65 \mathrm{~N}, 11.94 \%$, Found: C, $64.11 \mathrm{H}, 3.50 \mathrm{~N}, 11.83 \%$. ${ }^{1} \mathrm{H}$ NMR spectrum was not obtained, owing to the insolubility in the usual NMR solvents.

\subsubsection{3,3 '-(4,4'-dihydrazono biphenyl)bis (2,4-chromandione) (4k)}

Black solid, Yield: 68\% IR (KBr, ímax $\left./ \mathrm{cm}^{-1}\right): 3240(\mathrm{NH})$, 3019 (CH, Ar.), 1725 ( $\mathrm{C}=\mathrm{O}$, lactone), $1629(\mathrm{C}=\mathrm{O}, \mathrm{C}-4)$, $1608(>\mathrm{C}=\mathrm{N}), 1550(\mathrm{C}=\mathrm{C}-\mathrm{NH}-\mathrm{N}=), 1330\left(\mathrm{C}_{\text {arom. }}-\mathrm{N}\right) . \mathrm{MS} m / z$ (\%): $530\left(\mathrm{M}^{+}, 11\right), 397$ (16), 381 (9), 380 (100), 286 (11), 268 (14), 215 (8), 214 (17), 203 (35), 201 (25), 188 (19), 161 (15), 120 (30), 119 (25), 118 (13), 114 (16), 98 (10), 90 (9), 85 (17), 84 (23), 77 (38), 67 (13), 56 (22), 55 (52). Anal. Calcd. for $\mathrm{C}_{30} \mathrm{H}_{18} \mathrm{~N}_{4} \mathrm{O}_{6}(530.12)$ : $\mathrm{C}, 67.92 \mathrm{H}, 3.42 \mathrm{~N}$, $10.56 \%$, Found: C, 67.77 H, 3.54 N, $10.43 \%$. ${ }^{1} \mathrm{H}$ NMR spectrum was not obtained, owing to the insolubility in the usual NMR solvents.

\subsection{Dyeing and Fastness Determinations}

\subsubsection{Preparation of Dye Dispersion}

The required amount of the dye ( $2 \%$ shade) was dissolved in $1 \mathrm{~cm}^{3}$ acetone and then added dropwise with stirring to a solution of Setamol WS (sodium salt of a condensation product of naphthalene sulfonic acid and formaldehyde) as anionic dispersing agent of BASF. The dye was precipitated in a fine dispersion ready for use in dyeing after evaporation of the solvent by warming. 


\subsubsection{Dyeing of Polyester Fabrics}

The dye bath ( $1: 20$, good to dye liquor ratio) in a sealed stainless steel dye pots of $250 \mathrm{ml}$ capacity in "Galvanin-Marino VI-Italy" dyeing machine. Additional dispersing agent $(0.5-1.0 \mathrm{~g} / \mathrm{l})$ was added and the $\mathrm{pH}$ of the bath adjusted to 5.5 using glacial acetic acid. Dyeing carried out by raising the dye bath temperature from 20 to $130^{\circ} \mathrm{C}$ at a rate of $3{ }^{\circ} \mathrm{C} / \mathrm{min}$ and holding at this temperature for $60 \mathrm{~min}$ before rapidly cooling to $50^{\circ} \mathrm{C}$ at $9.9^{\circ} \mathrm{C} / \mathrm{min}$. The dyed fabrics were then rinsed with cold water, reduction-cleared using sodium hydroxide $(2 \mathrm{~g} / \mathrm{l})$ and sodium hydrosulphite (1 $\mathrm{g} / \mathrm{l})$ and soaped with $2 \%$ nonionic detergent and ammonia (pH 8.5) at $50^{\circ} \mathrm{C}$ for $30 \mathrm{~min}$ to improve washing fastness.

\subsubsection{Color Fastness Tests}

The color fastness of dyeing was evaluated using the standard method[17] and given in Table 1. The fastness to light, sublimation and perspiration was assessed in accordance with AATCC-15 (1985). The rubbing fastness test was carried out with a crockmeter (Atlas) in accordance with AATCC-88 (1988) and the wash fastness test in accordance with IS: 765-1979.

\subsubsection{Color Assessment}

The colorimetric parameters (Table 2) of the dyed polyester fabrics were determined on a reflectance spectrophotometer (Gretag Macbeth CE 7000a), equipped with a D65/108 source and barium sulphate as standard blank, UV excluded specular component included and three repeated measurements average settings.

\section{Results and Discussions}

\subsection{Synthesis and Tautomeric Structure}

The synthetic approach to the target azo dyes is outlined in Scheme 1. The starting material, 4-hydroxycoumarin (3), was prepared by the Claisen condensation of 2-hydroxyacetophenone (1) with the diethylcarbonate (2) in the presence of sodium hydride as previously described[18]. The coupling of $\mathbf{3}$ with a variety of aromatic diazonium salts in an ethanolic sodium hydroxide solution at $0-5^{\circ} \mathrm{C}$ produced the respective of 3-aryl(hetaryl)hydrazono-2,4chromandiones 4a-I (named as 2,3,4-chromantrione-3-aryl (hetaryl)hydrazones by the authors). In a similar manner coupling of each tetrazotized $p$-phenylenediamine and benzidine with two moles of $\mathbf{3}$ under the same conditions afforded the respective bishydrazono derivatives $\mathbf{4 j}$ and $\mathbf{4 k}$ (Scheme 1).

The structures of the isolated products $\mathbf{4 a - k}$ were established by their spectroscopic (UV, IR, ${ }^{1} \mathrm{H}$ NMR and MS) data and elemental analyses (see experimental). To assign the actual tautomeric and isomeric structure(s) of such products, their spectral data were examined.

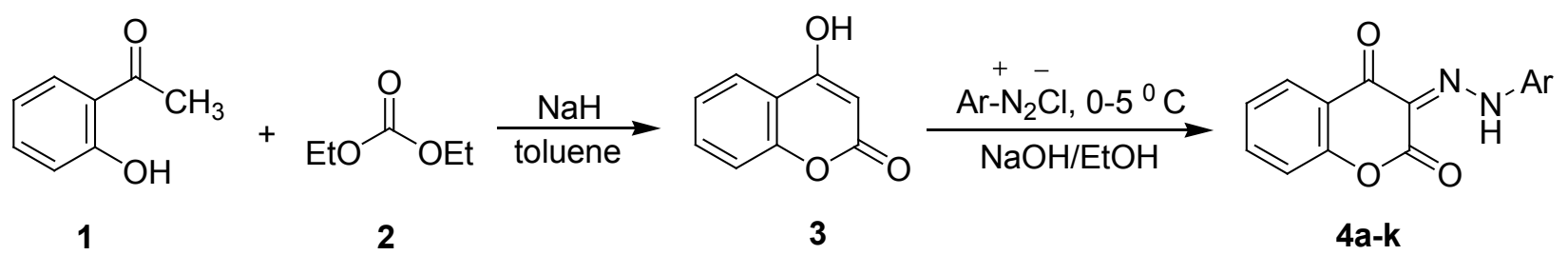

1

2

3

4a-k
a: $\mathrm{Ar}=\mathrm{C}_{6} \mathrm{H}_{5}$
b: $\mathrm{Ar}=4-\mathrm{Me}-\mathrm{C}_{6} \mathrm{H}_{4}$
c: $\mathrm{Ar}=4-\mathrm{MeO}-\mathrm{C}_{6} \mathrm{H}_{4}$
d: $\mathrm{Ar}=4-\mathrm{Cl}-\mathrm{C}_{6} \mathrm{H}_{4}$
e: $\mathrm{Ar}=4-\mathrm{Br}-\mathrm{C}_{6} \mathrm{H}_{4}$
f: $\mathrm{Ar}=4-\mathrm{NO}_{2}-\mathrm{C}_{6} \mathrm{H}_{4}$
g: $\mathrm{Ar}=2,4-\mathrm{Cl}_{2}-\mathrm{C}_{6} \mathrm{H}_{3}$
h: $\mathrm{Ar}=4-\mathrm{C}_{6} \mathrm{H}_{4}-\mathrm{N}=\mathrm{N}-\mathrm{Ph}$<smiles>Cc1c(C)n(C)n(-c2ccccc2)c1=O</smiles><smiles>O=C1Oc2ccccc2C(=O)/C1=N/Nc1ccc(I)cc1</smiles><smiles>[Y]c1ccc(NN=C2C(=O)Oc3ccccc3C2=O)cc1</smiles>

Scheme 1. Synthesis of 3-aryl(hetary)hdrazono-2,4-chromndiones 4a-k<smiles>C=C[Al]N=Nc1c(O)c2ccccc2oc1=O</smiles>

(A)<smiles>[O]c1oc2ccccc2c(=O)c1N=N[Al]</smiles>

(B)<smiles>CCC1(N=N[Ga])C(=O)Oc2ccccc2C1=O</smiles>

(C)<smiles>NC(=[W])N/N=C1\C(=O)Oc2ccccc2C1=O</smiles>

(D)

Figure 1. Possible tautomeric structures of 3-arylhdrazono-2,4-chromandine(A-D) 
As shown in Figure 1, compounds under scrutiny can have four possible tautomeric structures A-D. In a preliminary examination of compounds $\mathbf{4 a - k}$ gave, as expected, two main bands in electronic absorption spectra. The first band was observed in the wavelength range 252-260 nm in dioxane solution that could be assigned to the low energy $ð$ ¿ ${ }^{*}$ transition of the pyranone system[19,20]. The second band within the 416-438 $\mathrm{nm}$ range is analogous to that reported for $\varnothing_{-}{ }^{*}$ transition of the hydrazone group[21]. Moreover, absorption band attributed to azo structure between $332-360 \mathrm{~nm}[22,23]$ is missing. This excludes the possibility of azo structures (A)-(C), and provides support for the hydrazone structure (D) as the most plausible tautomeric structure.

Deconvolution of the IR spectra of that compounds 4a-K revealed, in each case, a weak NH band in the 3240-3177 $\mathrm{cm}^{-1}$ region, two carbonyl absorption bands in regions 1740-1725 and 1640-1627 cm $\mathrm{cm}^{-1}$ characteristic for 2-pyranone and 4-pyranone, respectively. The presence of $\mathrm{NH}$ and two $>\mathrm{C}=\mathrm{O}$ absorption bands is incompatible with the hydroxyazo structure $(\mathbf{A})$ and $(\mathbf{B})$. That the $>\mathrm{C}=\mathrm{O}$ bands are markedly lower in frequencies than that of the parent 4-hydroxycoumarin, excludes the possibility of the azo-keto structure $(\mathbf{C})$. The downward shift of the $>\mathrm{C}=\mathrm{O}$ stretch together with that of $\mathrm{NH}$ can be rationalized in terms of the keto-hydrazone structure (D). In the latter, the increased degree of conjugation of the $>\mathrm{C}=\mathrm{O}$ with $\mathrm{C}=\mathrm{N}$ double bond and the possible intramolecular hydrogen bonding between the $>\mathrm{C}=\mathrm{O}$ and the hydrazone $\mathrm{NH}$ results in reducing the force constant of the $>\mathrm{C}=\mathrm{O}$ group and thus leads to lowering of its stretching frequency. The fact that the coupling products $\mathbf{4 a - k}$ show evidence for intramolecular hydrogen bonding is in favor of hydrazone structure (D), since compounds with structure (C) would not possess this property. Since it has been deduced that the compounds exist as hydrazone structure, a band due to the $\mathrm{C}=\mathrm{N}$ linking would be expected in the region $1604-1613 \mathrm{~cm}^{-1}[5,6]$. The prominent band occurs around $1545 \mathrm{~cm}^{-1}$ assigned to the benzene ring $\mathrm{C}=\mathrm{C}$ skeletal vibration associated with the $-\mathrm{NH}-\mathrm{N}=$ linkage in the 4-position on the coumarin ring[5]. On the other hand, the stretching vibration of the $\mathrm{C}_{\text {arom. }}-\mathrm{N}$ linkage show band between $1355-1330 \mathrm{~cm}^{-1}$ in their spectra [5].

Corroborative evidence that compounds under scrutiny exist in the tautomeric form (D) comes from inspection of the ${ }^{1}$ HNMR spectral data. Notably, the ${ }^{1}$ HNMR spectra show the significantly downfield-shifted resonances at about $16 \mathrm{ppm}$ suggest the presence of protons that engage in strong hydrogen bonding[24] (Fig. 1). Unfortunately, this information alone is questionable and open to criticism to distinguish between the azo and hydrazone tautomers (Fig. 1), as both have D-H - A (D: hydrogen-bond donor A: hydrogen-bond acceptor).
An initial clue for assigning the tautomeric state was provided by the ${ }^{1} \mathrm{HNMR}$ spectra indicate that compounds under scrutiny exist as the hydrazone form (D) rather than as an equilibrium mixture of several tautomeric species. It was reported that the hydrazone $\mathrm{NH}$ proton resonance appears approximately between 13.0 and $16.0 \mathrm{ppm}$, in $o$ - and $p$-hydroxyazo dyes[25,26]. Also, the spectral data do not show any more high field signals around $12.4 \mathrm{ppm}$ which is reported for the O-H of form (A),(B) or around $5.5 \mathrm{ppm}$ for $\mathrm{CH}$ of tautomeric form $\mathbf{C}$ of the annulated similar compounds, respectively[27]. It is noteworthy in this connection that the rule recently formulated by Lee et al.[28] evidence that "While the low energy barrier for rotation around the $\mathrm{C}-\mathrm{N}$ single bonds in the azo tautomer would give rise to a single set of resonances as a population-averaged signal, the restricted rotation around the $\mathrm{C}=\mathrm{N}$ double bonds in the hydrazone form would lead to two distinctive geometric isomers".

Hence, a careful look at the ${ }^{1}$ HNMR spectrum (see Fig. 2.) shows a small signal at about $14 \mathrm{ppm}$. As, it was reported in many publications that arylhydrazones of diketone or triketone exist in solution as a pair of intramolecularly H-bonded hydrazone isomers[29,30]. This compounds, therefore, prefers to stay exclusively in the hydrazone structure and they may be periodically converted from $E$-isomer to Z-isomer by the occasional "tunnelling" of hydrogen atoms which centered between nearly equivalent potential minima associated with the two pairs of oxygen atoms that compete to form the intramolecularly hydrogen bond (IMHB). Furthermore, it is probable that the charge density play a considerable part in the strength of the hydrogen bonding[31]. IR spectra showed $\mathrm{C}=\mathrm{O}$ stretching frequency of ketone group is lower than that of lactone group. Consequently, the charge density would be expected to be greater on the oxygen of a ketone group than of a lactone group. One might thus expect that the ketone group would be preferentially involved in the intramolecularly H-bonded system to indicate that $\mathbf{D}$ ( $Z$-isomer) is more stable than $\mathbf{D}$ ( $E$-isomer), which is in agreement with the isomer ratio observed in the ${ }^{1}$ HNMR spectra $(Z: E \sim 84.5: 15.5)$. This evidence is in agreement with those previous values reported by the computational study[11] or ${ }^{15}$ NNMR spectroscopy [10].

An additional proof of this proposed tautomeric structure (D) is found in the mass spectral fragmentation analysis. Mass spectra of all the compounds $\mathbf{4 a - k}$ showed molecular ion $\left(\mathrm{M}^{+}\right)$peaks at the expected $m / z$ values which confirmed their molecular weights. The major fragmentation pattern appeared by the cleavage of $(\mathrm{Ar}-\mathrm{NH})$ bonds of the hydrazone moiety in high relative abundance (see Fig. 4)[32]. Moreover, the formation of an $\mathrm{M}-\mathrm{N}_{2}$ ion is specific for compounds that contain an azo group is missing $[33,34]$. 


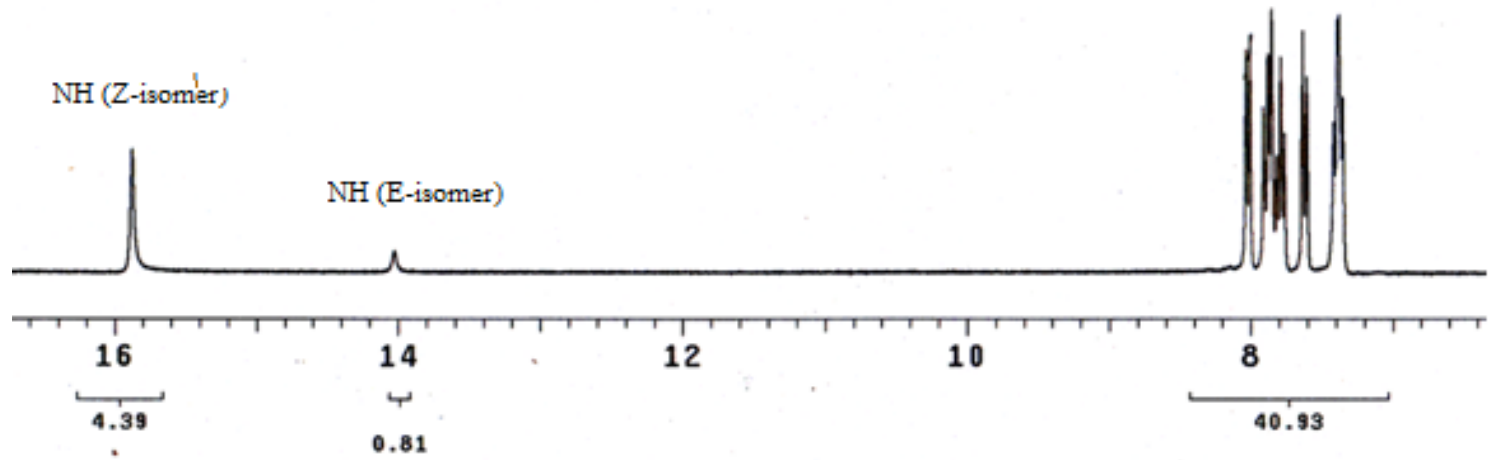

Figure 2. Partial 1H NMR spectra of $4 \mathbf{e}$ in DMSO-d6 in which peaks are assigned to the presence of the two isomers of E and Z-isomer (see Fig. 3)<smiles>O=C1Oc2ccccc2C(=O)/C1=N/[AlH2]</smiles>

Z-configuration<smiles></smiles>

E-configuration

Figure 3. Possibilities configuration for the compounds $\mathbf{4 a - k}$ as they exist in the tautomeric form(D)
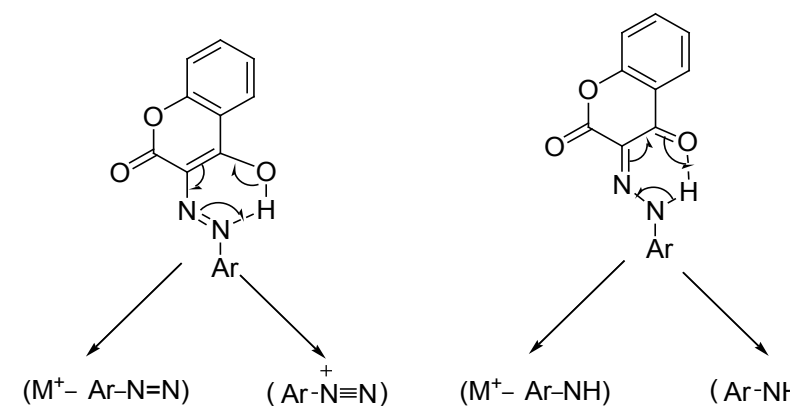

Figure 4. Fragmentation pathway appeared for the hydrazone and azo moiety as tepresentative example

\subsection{Dyeing and Fastness Properties}

The development of disperse dyes "Dyes insoluble in water and applied from aqueous dispersion rather than from solution" was a revolutionary solution to the problem of coloration of synthetic fibers. The dyes were essentially insoluble in water and were prepared for application by being ground, in the presence of dispersing agents, to microscopically fine particles of the order of a few microns and, then, by pan drying the resultant suspension. The resulting readily dispersible solid could then dye the more hydrophobic acetate fiber by partitioning into the fiber from low dye bath concentrations. The synthesized disperse dyes under investigation 4a-k were applied to polyester fabric at $2 \%$ shade by high-temperature pressure technique $\left(130^{\circ} \mathrm{C}\right)$. The dyes on polyester fabrics were evaluated in terms of their fastness properties as shown in Table 1.

\subsubsection{Fastness to Washing}

The dyed polyester fabrics have very good fastness to washing according to the international Geometric Grey

scale[35] and this may be attributed to inadequate diffusion of dye molecule into the fabrics.

\subsubsection{Fastness to Perspiration: (Acid and Alkaline)}

The high ratings for change in color at both acidic and alkaline conditions indicate that the sensitivity of the dyed samples are not related to $\mathrm{P}^{\mathrm{H}}$. This may be due to the stability of the dyes towards degradation under either acidic or basic conditions.

\subsubsection{Fastness to Rubbing}

The test is designed to determine the amount of color transferred from the surface of colored fabrics to another surface by rubbing. Most of the dyes have a good rubbing fastness and this may be attributed to adequate diffusion of dye molecule into the fabrics.

\subsubsection{Fastness to Sublimation}

Sublimation fastness properties of synthesized dyes expressed as color staining on the undyed polyester piece ranged from moderate to good according to the international Geometric Grey Scale[35]. It is dependent upon the structure of the coupling component and was influenced by the substituents in the coumarin ring. Most of the dyes showed good sublimation fastness.

\subsubsection{Fastness to Light}

It is significantly depended on nature of the substituents which change the electron density around hydrazo group. The high fastness to light may be attributed to electron accepting groups. This agrees with the notion that the azo compounds appended with electron-withdrawing substituents on the diazo components are less prone to photofading[36]. Generally, the prepared dyes showed satisfactory fastness to light ranging 6-7 according to the international Geometric Grey Scale[35].

\subsection{Color Assessment}

The color parameters (Table 2) of the dyed polyester fabrics were measured using a spectrophotometer (GretaMacbeth Color Eye 7000A, USA) under illuminant D65, with a $10^{\circ}$ standard observer. The assessment of 
color-dyed fabrics was made in terms of tristimulus colorimetry. The following CIELAB coordinates are measured, lightness $\left(\mathrm{L}^{*}\right)$, chroma $\left(\mathrm{C}^{*}\right)$, hue angle from $0^{\circ}$ to $360^{\circ}(\mathrm{h}),\left(\mathrm{a}^{*}\right)$ value represents the degree of redness (positive) and greenness (negative) and $\left(b^{*}\right)$ represents the degree of yellowness (positive) and blueness (negative). The K/S value which has been employed as the dye uptake or color strength was calculated for each dyed specimen as well as for an undyed one at a maximum absorption wavelength of 360 $\mathrm{nm}$ from the reflectance values using the Kubelka-Munk equation[36] as follows

$$
\mathrm{K} / \mathrm{S}=(1-\mathrm{R})^{2} / 2 \mathrm{R}
$$

where $\mathrm{K}$ is the coefficient of absorption $\mathrm{S}$ is the coefficient of scattering $R$ is the reflectance value of the fabric at peak wavelength. The parent dyestuff in each group is taken as the standard in the color difference calculation $\left(\Delta \mathrm{L}^{*}, \Delta \mathrm{C}^{*}\right.$, and $\left.\Delta \mathrm{H}^{*}\right)$. The results were obtained using CIELAB techniques, and are given in Table 2 , where $\Delta \mathrm{L}^{*}$ is the lightness difference, $\Delta \mathrm{C}^{*}$ is the chroma difference, and $\Delta \mathrm{H}^{*}$ is the hue difference. A negative sign of $\Delta \mathrm{L} *$ indicates that the dyed fabric becomes darker than the standard, whereas a positive sign indicates that the dyed fabric becomes lighter than the standard. A negative sign of $\Delta C^{*}$ indicates that the dyed fabric becomes duller than the standard, whereas a positive sign indicates that the dyed fabric becomes brighter than the standard. A negative sign of $\Delta \mathrm{H}^{*}$ indicates that the color shifted to a red color, while a positive sign indicates that the color shifted to yellowish. The results are shown in Table 2 tend to give the following conclusions:

i. $\mathrm{K} / \mathrm{S}$ values in the dyes under investigation $\mathbf{4 a - k}$ vary from 40.08 to 41.39 , which all members of this groups increases strength of the K/S value of the polyester fabric compared with that of the parent 4a. Dyes $\mathbf{4 h - k}$ which contain bis-hydrazo or hetero moiety are characterized by higher K/S values compared with their analogues $\mathbf{4 a - g}$, indicating that the introduction of bis-hydrazo or hetero moiety in dyes increases the color strength on polyester fabrics.

ii. The color hues of the dyes under investigation 4a-k on polyester fabric are shifted to the yellowish direction on the yellow-blue axis according to the positive values of $b^{*}$.

iii. The color hues of the synthesized dyes $\mathbf{4 a - k}$ on polyester fabrics are shifted to the reddish direction on the red-green axis as according to the positive values of $\mathrm{a}^{*}$ for these dyes.

iv. In general, dyeings with the dyes $\mathbf{4 g - k}$ were darker and duller than the other dyes $\mathbf{4 a - f}$ according to the values of $\mathrm{L}^{*}$ and $\mathrm{C}^{*}$.

Table 1. Fastness properties ${ }^{\mathrm{a}}$ of the synthesized dyes $\mathbf{4 a - k}$ on polyester fabrics

\begin{tabular}{|c|c|c|c|c|c|c|c|c|}
\hline \multirow{2}{*}{ Compound no. } & \multirow{2}{*}{ Washing } & \multicolumn{2}{|c|}{ Perspiration } & \multicolumn{2}{|c|}{ Rubbing } & \multicolumn{2}{|c|}{ Sublimation fastness } & \multirow{2}{*}{$\begin{array}{c}\text { Light (80 } \\
\text { h) }\end{array}$} \\
\hline & & Acid & Alkali & Dry & Wet & $180^{\circ} \mathrm{C}$ & $210^{\circ} \mathrm{C}$ & \\
\hline $4 a$ & $4-5$ & $4-5$ & $4-5$ & 4 & $4-5$ & $3-4$ & $3-4$ & 7 \\
\hline $4 b$ & $4-5$ & $4-5$ & $4-5$ & 4 & $4-5$ & $3-4$ & 3 & $6-7$ \\
\hline $4 c$ & $4-5$ & 4 & $4-5$ & 4 & $4-5$ & 4 & 4 & 6 \\
\hline $4 d$ & $4-5$ & $4-5$ & 4 & 4 & $4-5$ & 4 & 4 & 7 \\
\hline $4 e$ & $4-5$ & 4 & 4 & 4 & 4 & 4 & $3-4$ & 7 \\
\hline $4 f$ & $4-5$ & 4 & $4-5$ & 4 & $4-5$ & $3-4$ & $3-4$ & 7 \\
\hline $4 \mathrm{~g}$ & 4 & 4 & $4-5$ & 4 & 4 & 3 & 3 & $6-7$ \\
\hline $4 h$ & 4 & 4 & 4 & $3-4$ & $3-4$ & $3-4$ & 4 & 6 \\
\hline $4 i$ & $4-5$ & $3-4$ & $3-4$ & 4 & 4 & 4 & 4 & 6 \\
\hline $4 j$ & 4 & 4 & 4 & 3 & $3-4$ & 3 & 3 & 6 \\
\hline $4 k$ & 4 & 4 & $4-5$ & $3-4$ & 4 & 3 & 3 & 6 \\
\hline
\end{tabular}

$\mathrm{a}=$ light fastness, 1-8 scale washing, perspiration, rubbing and sublimation fastness, $1-5$ scale

Table 2. Color values of dyes $\mathbf{4 a - k}$ on polyester fabrics (light source D65/10 observer

\begin{tabular}{|c|c|c|c|c|c|c|c|c|c|c|c|}
\hline Compound no. & $\mathrm{K} / \mathrm{S}$ & $a^{*}$ & $b^{*}$ & $\mathrm{C}^{*}$ & $\mathrm{~L}^{*}$ & $\mathrm{H}^{*}$ & $\Delta \mathrm{a}^{*}$ & $\Delta \mathrm{b}^{*}$ & $\Delta \mathrm{C}^{*}$ & $\Delta \mathrm{L}^{*}$ & $\Delta \mathrm{H}^{*}$ \\
\hline $4 a$ & 40.08 & 9.2 & 91.7 & 92.2 & 79.5 & 84.2 & -- & -- & -- & -- & -- \\
\hline $4 b$ & 40.86 & 29.4 & 102.9 & 103.3 & 81.2 & 84.7 & 20.2 & 11.1 & 2.3 & 1.7 & 0.5 \\
\hline $4 c$ & 41.05 & 38.6 & 89.1 & 96.2 & 68.7 & 67.9 & 29.4 & 4.0 & 7.6 & -10.8 & -16.3 \\
\hline $4 d$ & 41.02 & 19.8 & 100.4 & 100.5 & 82.5 & 88.5 & 10.6 & 8.7 & 8.3 & 3.0 & 4.3 \\
\hline $4 e$ & 40.47 & 29.2 & 101.6 & 101.7 & 82.3 & 88.1 & 20.0 & 9.9 & 9.5 & 2.8 & 3.9 \\
\hline $4 f$ & 40.60 & 28.6 & 86.1 & 100.4 & 76.8 & 93.1 & 19.2 & 4.5 & 7.8 & 2.4 & 5.8 \\
\hline $4 \mathrm{~g}$ & 40.44 & 21.6 & 86.1 & 86.3 & 73.4 & 86.3 & 12.4 & -5.6 & -5.9 & -6.1 & 2.1 \\
\hline $4 h$ & 41.30 & 18.5 & 31.9 & 44.1 & 64.3 & 46.3 & 11.1 & -60.1 & -52.8 & -21.5 & -31.4 \\
\hline $4 i$ & 41.18 & 24.9 & 24.3 & 32.6 & 65.1 & 48.2 & 15.7 & -67.4 & -59.6 & -14.4 & -36.0 \\
\hline $4 j$ & 41.39 & 15.3 & 29.1 & 49.7 & 48.1 & 35.6 & 6.1 & -62.6 & -42.5 & -31.4 & -48.6 \\
\hline $4 k$ & 41.36 & 25.7 & 58.1 & 68.1 & 67.8 & 58.4 & 16.5 & -33.6 & -24.1 & -11.7 & -25.8 \\
\hline
\end{tabular}




\section{Conclusions}

In conclusion, we described the synthesis and spectroscopic properties of a series of disperse azo dyes $\mathbf{4 a - k}$ including coumarin ring. The spectroscopic data of the dyes prepared has provided a decisive evidence that such compounds exist predominantly in the hydrazo structure (D) as a mixture of $Z$ and $E$-isomer with ratio $\sim 84.5: 15.5$. Finally the prepared dyestuffs were dyed on polyester fabrics and subsequently their dyeing properties, light, washing, perspiration, rubbing and sublimation fastnesses were determined. All these properties were proved to be good. From these investigations, it may be concluded that dyestuffs derived from 4-hydroxycoumarin are reasonable azo disperse dyestuffs giving good all round properties on polyester fabrics.

\section{ACKNOWLEDGMENTS}

Financial support of this research through a grant from the Academy of Scientific Research and Technology, Egypt (to Moaz M. Abdou) is greatly appreciated. The authors express their appreciation and gratitude to the authorities of the Laboratories and Research sector in El-Nasr Company for Textile, Spinning and Weaving, El-Mahalla El-Kubra, Egypt for dyeing assessment, fastness tests and color measurements.

\section{REFERENCES}

[1] O Annen, R Egli, R Hasler, B Henzi, H Jakob and P Matzinger, Rev. Prog. Coloration, 17 (1987) 72.

[2] R Hamprecht and A Westerkamp, Ullmann's Encyclopedia of Industrial Chemistry. 6th ed., Vol. 10, (2003). 573.

[3] RM Christi, RR Mather and RH Wardman, The Chemistry of Color Application. Blackwell Science Ltd: Oxford, (2000) 13.

[4] H Klaus, Industrial Dyes, Chemistry, Properties, Applications. Wiley-VCH: Weinheim, (2003) 20.

[5] MA Metwally, S. Bondock, SI El-Desouky and MM Abdou, $J$. Korean Chem. Soc., 56 (2012) 82.

[6] MA Metwally, S Bondock, SI El-Desouky and MM Abdou, Dyes Pigm., 2012 (submitted).

[7] MH Elnagdi, HM Fahmy, MA Morsi and SK El-Ees, Indian. J. Chem., 16B (1978) 295.

[8] F Karci and N Ertan, Dyes Pigm., 64 (2005) 243.

[9] CF Huebner and KP Link, J. Am. Chem. Soc. 67 (1945) 99.

[10] CH Yoder, RC Barth, WM Ritcher and FA Snavely, J. Org. Chem., 37 (1972) 4121.

[11] AS Shawali, NMS Harb and KO Badahdah, J. Heterocycl. Chem., 22 (1985) 1397.
[12] F Karci, Color. Technol., 121 (2005) 275.

[13] MR Yazdanbakhsh, A Ghanadzadeh and E Moradi, J. Mol. Liq., 136 (2007) 165.

[14] MA Metwally, S. Bondock, SI El-Desouky and MM Abdou, $J$. Korean Chem. Soc., 56 (2012) 348.

[15] (a) MA Metwally, S. Bondock, SI El-Desouky and MM Abdou, Int. J. Modern Org. Chem., 1 (2012) 19. (b) MA Metwally, S. Bondock, SI El-Desouky and MM Abdou, Int. J. Modern Org. Chem., 1 (2012) 165.

[16] MA Metwally, S. Bondock, SI El-Desouky and MM Abdou, Color. Technol., (2012) (submitted).

[17] Anonymous. Standard Methods for the Determination of the Color Fastness of Textiles and Leather. $\left(5^{\text {th }}\right.$ ed.). Society of Dyers and Colorists, Bradford: UK, (1990) 619.

[18] JC Jung, YJ Jung and OS Park, Synth. Commun., 31 (2001) 1195.

[19] R Patzak and L Neugebauer, Monatsh. Chem., 82 (1951) 662.

[20] BG Engel, W Brzeski and PA Plattner, Helv. Chim. Acta., 32 (1949) 1752.

[21] SG Küçükgüzel and S Rollas, Farmaco, 57 (2002) 583.

[22] WU Malik, HG Garg and V Arora, J. Pharm. Sci., 60 (1971) 1738.

[23] HG Garg and V Arora, J. Pharm. Sci., 61 (1972) 130.

[24] JA Pople, WG Schneider and HJ Bernstein, High-Resolution Nuclear Magnetic Resonance, McGraw-Hill Book Co., Inc.: New York, 1959, pp 400.

[25] A Lycka, Z Vrba and M Vrba,. Dyes Pigm., 47 (2000) 45.

[26] A Lycka, Dyes Pigm., 43 (1999) 27.

[27] VF Traven, VV Negrebetsky and LI Vorobjeva, Can. J. Chem., 75 (1997) 377.

[28] HY Lee, X Song, H Park, MH Baik and D Lee, J. Am. Chem. Soc., 132 (2010) 12133.

[29] CG McCarthy, In The Chemistry of the Carbon-Nitrogen Bond Patai, S., Ed. John Wiley and Sons: New York, (1970) 392.

[30] (a) HC Yao, J. Org. Chem,. 29 (1964) 2959. (b) AK Bose, I Kugajevsky, Tetrahedron, 23 (1967) 1489. (c) GJ Karabatsos and RA Taller, Tetrahedron, 24 (1968) 3923. (d) AD Mitchell and DC Nonhebel, Tetrahedron Lett., 16 (1975) 3859. (e) V Bertolasi, V Ferretti, P Gilli, YM Issa and OE Sherif, J. Chem. Soc., Perkin Trans., 2 (1993) 2223.

[31] AD Mitchell and DC Nonhebel, Tetrahedron, 35 (1979) 2013.

[32] MF Abdel-Megeed, Spectrosc Lett., 20 (1987) 291.

[33] SW Tam, The Chemistry of the Hydrazo, Azo, and Azoxy Groups. Wiley: New York, (1975) 109.

[34] EV Brown, J. Heterocycl. Chem., 6 (1969) 571.

[35] SDL. Atlas Ltd. P.O. Box 162, Crown Royal, Shawcross St., Stockport SK1 3JW.

[36] PF Gordon, P Gregory, Organic Chemistry in Color. Springer-Verlag: Berlin, (1983) 289. 